\title{
The Financial Dynamics of University-Based Firms. The Effect of Different Financing Sources on the Firm Financial Performance
}

\author{
Sabrina Saccomandi \\ Università Telematica San Raffaele Roma
}

\begin{abstract}
The research aims to investigate the financing sourcing of the university-based firms in the form of university spinoff (USOs), namely the in-house finance, the debt finance and equity finance, jointly with their impact on the financial performance of USOs. A panel sample of 621 Italian USOs was examined over the period 2004-2013. The results show a positive but low effect of in-house finance on the financial performance of USOs, while debt finance has positive and relevant impact on the financial performance of USOs. Taking into account the effect of equity finance, the evidence is comparable to those associated with the effect of debt finance. However, the most significant impact is exercised by the institutional investors in the form of venture capital and private equity. This evidence shows that, in the entrepreneurial university context, these dedicated investors have the most beneficial and central role in improving the financial development of university-based firms.
\end{abstract}

Keywords: university-based firms; USOs; firm finance; in-house finance, debt finance; equity finance, VC finance; PE finance; firm financial performance.

\section{Introduction}

In view of the evolving process of integration of markets and the globalization of economies, companies in welldeveloped countries find themselves facing various pressures, such as competition from new entrants and the obsolescence of their products and services, which lead to a contraction in demand and therefore, ultimately, negatively affect the economic growth (Buckley and Hashai, 2020; Petricevic and Teece, 2019). To counter this phenomenon, it is necessary that the economic system is able to innovate, that is, to create new companies with high added value, technological or scientific or that exploit innovative ideas (Soete, 2014; Alvarez et al., 2019).

However, innovation must be developed so as to find proper application in the economy and, therefore, it becomes essential to implement the so-called technology transfer process (Audretsch et al., 2014; Cho and Shenkoya, 2020)University spin-offs are one of the tools available to researchers and entrepreneurs to implement this transfer.

In Italy, the university spin-off phenomenon is relatively new and has had a significant development since the 2000s. This has also happened thanks to the more relevant interventions of universities, with the creation andstrengthening of assistance services for start-ups and actions to enhance and protect intellectual property. Furthermore, in some cases, universities have achieved more effective coordination with subjects such as incubators, investors, industrial partners and, finally, have issued ad hoc regulations, so as to provide a clearer regulatory framework.

Despite the importance of this tool, most of the studies on university spin-offs in Italy have focused on surveys of the phenomenon and descriptive analysis, with a focus on the internal and external determinants of the success of spin-offs.

Indeed, the previous literature, for example, instigates the growth (both as a change in turnover and as a number of employees) (Balderi and Piccaluga, 2010; Colombo and Grilli, 2010; Balderi et al., 2011), the productivity and the degree of innovativeness - measured for example by the number of patents - as well as income performance (Bolzani et al., 2014). However, it is necessary not only to understand how many research spin-offs are created and performed, but also to investigate the quality of the projects and the results achieved in terms of financing methods and choices over time.

The present work therefore aims to fill this gap in the literature by investigate the phenomenon of research spin-offs answering the following research question:

What are the impacts of the different financial sources (namely in-house finance, debt finance and equity finance institutional finance) on the financial performance of the USOs?

To this end, we will focus on analyzing a sample of 621 spin-offs in the period between 2003 and 2014.

The work is organized as follows: the second paragraph presents a review of the main contributions of the literature. The third paragraph is dedicated to the description of the sample; then the results are presented and, finally, some conclusive considerations are developed. 


\section{Review of the literature}

The theoretical perspective that better integrate the conceptual framework about the development of university spin-offsis the Resource Based View of the firm (RBV).

With reference to the first line, the RBV refers to the ability to acquire and organize the resources and skills that favor the success of businesses (Barney, 2001; Kull et al., 2016). Within this framework, there are numerous studies with specific insights into the context of research spin-offs.

In the case of spin-offs, the relevant resources identified in the literature are: (1) the technological resources, intended both as equipment for plants and laboratories either as the availability of patents or other intellectual property rights; (2) the quality of human resources, in terms of scientific skills, of entrepreneurial spirit and managerial skills; (3) the financial resources, in terms of the amount of capital raised and the network forthe involvement of new shareholders; (4) the ability to attract new financial shareholders (venture capitalist and business angel) and / or industrial.

With regard to financial resources, great attention is paid in the literature to the ability of spin-offs to attract venture capital to a sufficient extent to guarantee development (Heirman and Clarysse, 2004; Huynh et al., 2017), although it represents a necessary, but not a sufficient factor for growth (Moray and Clarysse, 2005). Risk capital allows, in fact, to create a competitive advantage, allowing the spin-off to make technological investments from the first years of life, as well as investments in management activities, and to cover the financial needs in the period in which the revenues are scarce and discontinuous or in the presence of economic difficulties (Minola et al., 2019).

The literature, however, frequently finds that the start-up capital of spin-offs is small, and this happens for two reasons. First, the needs spin-off financials may initially be lower than similar companies in the industrial world (Mathisenand Rasmussen, 2019; Yagüe-Perales and March-Chordà, 2012), thanks to the possibility for spin-offs to benefit from subsidies, financial aid and logistical support made available by the university or by the promoting body. Secondly, the founders' ability to contribute capital can be limited, as these are often natural persons who cannot access large amounts of personal assets to be contributed as capital in the spin-off (Rodríguez-Gulías et al., 2017).

The literature has highlighted, in particular, the difficulty in attracting risk capital, typical of companies with a high technological or scientific research content (Carpenter and Petersen, 2002; Fini et al., 2017) and the various implications related to the type of lenders. In the case of spin-offs, the difficulties are exacerbated by the fact that the contribution from universities is often limited and moreover, as already mentioned, individual shareholders generally prevail in the shareholder structure and this further hinders the ability to attract other types of shareholders who intervene in a purely financial logic.

The benefits deriving from the entry into the share capital of subjects other than individuals and universities or research institutes promoters are many and not only linked to the contribution of capital, but also of skills. For example, with explicit reference to the role of venture capital, international studies show how the contribution of adequate levels of capital is able to foster growth (Baum and Silverman, 2004; Heirman and Clarysse, 2004), while scouting and coaching carried out by venture capital operators makes it possible to support the most gifted companies, increasing their chances of success (Colombo and Grilli, 2010). Other research shows, however, that this relationship is not always valid (Guerrero andUrbano, 2012).

Although some empirical studies have shown that in some countries, university spin-offs attract venture capital funds more than start-up companies far from academia and industrial groups (Yagüe-Perales and March-Chordà, 2012), the participation of these entities in the capital of the spin-offs remains limited. The causes of the reduced participation of venture capitalists in the capital of spin-offs are, in fact, the strong information asymmetries and the reduced management capacity of entrepreneurs (Oskarsson and Schläpfer; 2008; Florio, 2019). On the other hand, the researchers themselves are sometimes prejudiced against venture capitalists for fear of income pressures and the possible loss of managerial autonomy (Guerrero et al., 2016).

Finally, looking at the other types of potential financiers, industrial companies show greater interest and willingness to enter the capital of university spin-offs than financial operators, but their links with these companies are not widespread in Italy anyway (Bolzani et al., 2014; Fini et al., 2018), perhaps due to a certain distance between the business and academic worlds, the result of prejudices that mutually distance the two parties. On the one hand, there is, in fact, the fear that academic entrepreneurs resist purely industrial logic and that they are bearers of priorities and cultures that are not completely permeable to those of industry; on the other side, the fear of excessive interference in management by the industrial shareholder remains (Lazzeri and Piccaluga, 2012).

Several empirical studies show, however, how the presence of industrial investors within the shareholder structure contributes to the success of the spin-off (Aggarwal et al., 2004; Prokop et al., 2019), both for the management support provided and for the commercial one. 


\section{Methodologies}

\subsection{Data}

In order to test the research hypothesis above, data about USOs were drawn from Netval databasethat is part of the 'Spin-off Italia' project and run in collaboration with Netval ， UniversitàPolitecnicadelle Marche and ScuolaSuperiore Sant Anna - Istituto di Management, which collects updated information about the complete population of active spin-offs in Italy. From the full dataset of the Netval database, we extracted only information related to the USOs, namely 1,275 firms. Since the Netval database does not contain financial information, we collected this latter by extracted data from Aida BdV database, an Italian subset of the ORBIS database, which contains financial, biographical and merchandise data of about 700,000 active Italian companies. Specifically, financial information is provided by Honyvem, which acquires and reprocesses all official accounts deposited with the Italian Chambers of Commerce. From the 1,275 USOs we eliminated those firms for which the data was not available in the Aida BdV database for the time period we are taking into account. Thus, the final panel sample consists of 621 Italian USOs, with data covering the period from 2003 to 2014 for an average of 1,640 firm-year observations.

\subsection{Variables}

\subsubsection{Dependent variable}

With the purpose of determining the financialperformance of the USOs sampled, the log of sales was used, (FINANCIAL PERFORMANCE). This form of measurement is usuallyrecognized in research analyzing the SME' financialperformance dynamics.

\subsubsection{Independent variables}

In order to determine the proxies for the USO' internal funding resourcesthe ROA index was used (Gaud et al., 2007; Lappalainen and Niskanen, 2012),measured as the ratio of earnings before interest, taxes, depreciation and amortization (EBITDA) to total assets (IN-HOUSE FINANCE).

With the aim to determine the access to debt financing of USO, the leverage index was used (DEBT FINANCE), measured as a company's debt ratio, i.e., financial debt to total assets (Vanacker and Manigart, 2010).

Further, with the purposeto determine the external equity finance of USOs, the share of external industrial firms/individual owners in the firm was used (EQUITY FINANCE) (Vanacker et al., 2014). The share of Private Equity and Venture Capital investors were used too (INSTITUTIONAL FINANCE).

\subsubsection{Control variables}

First, the relation between firm age and financial growth reveals that start-ups firms are expected to developquicker. However, literature show an inverse relation between firm age and growth (Davidsson et al., 2002). Hence, we controlled for firm age (AGE).

Second, we controlled for firm size, measured asthe number of the annual firm' employees (SIZE).

Third, dummy variables were used to control for industry specific fixed effects on the base of NACE rev 2 classification.

\subsection{Analytical approach}

With the aim to test the developed research question a linear regression estimation was used. In line detail, the following firm' financial growth function was defined, and it allows for time and firm fixed effects:

FINANCIALPERFORMANCE $E_{i t}=f\left(\beta_{0}+\beta_{1} I_{N}\right.$ HOUSEFINANCE $E_{i t}+$ $\beta_{2}$ DEBTFINANCE $E_{i t}+\beta_{3}$ EQUITYFINANCE $_{i}+\beta_{4}$ INSTITUTIONALFINANCE ${ }_{i}+\beta_{5} A G E_{i}+\beta_{6}$ SIZE $_{i t}+$ $\beta_{7}$ INDUSTRYEFFECTS $\left.{ }_{i t}+\delta_{t}+\varepsilon_{i t}\right)$

Where $i$ indexes USO and $\mathrm{t}$ indexes years. In addition, $\approx t$ is the time effect and $\varepsilon_{\mathrm{it}}$ is the error term.

\section{Findings}

\subsection{Descriptive statistics}

Table 1 shows the descriptive statistics of variables used in the study. The results showthat sampled firms show an average of financial performance of 5.1526, with a medium-low dispersion in the sample (S.D. $=0.8702$ ), and remarksthat the financial performance, measured term sales, are limited for the USOs sample, an issue shared by other typology of technology and knowledge-based firms. 
With regard to the financial sources of USOs, the results show thatthe internal finance, measured by ROA, reports a mean of 2.3924, remarking that USOs are quite constrained in the formation of in-housefinancial resources to invest in the technology transfer process. However, this result shows a high dispersion in the sample (S.D. = 27.3834), highlighting the significant heterogeneity in the internal financial structure of the USOs. With reference to the debt finance, measured by the leverage ratio, the results show a mean of 1.5913 , indicating that the USOs make an operational use of the debt financing. Nevertheless, taking into account that this information shows a significant dispersion in the sample (S.D. $=15.8276$ ), this denotes a larger variability in the capital structure of the USOs sampled.

Concerning the access to external equity finance, the results show a pretty low mean of the share of external firms/individual owners (mean of 0.3545), with a moderate dispersion in the sample (S. D. $=4.783448$ ), indicating that the involvement of external shareholders in the USOs ownership structure varies in a considerably manner between the sampled firms. Nevertheless, the share of institutional investors, in the form of private equity and venture capital investors. shows a higher mean higher of0.0202. Also, the result shows a medium-low heterogeneity in the sample (S.D.= 0.10160).

Table 1 - Descriptive statistics

\begin{tabular}{llllll}
\hline & $\mathrm{N}$ & Min. & Max. & Mean & S. D. \\
\hline FINANCIAL PERFOMANCE & 2,981 & 0 & 7.994004 & 5.152642 & .8702202 \\
IN-HOUSE FINANCE & 3,395 & -636.96 & 88.25 & 2.392489 & 27.38346 \\
DEBT FINANCE & 2,957 & -114.82 & 660.55 & 1.591356 & 15.82762 \\
EQUITY FINANCE & 7,116 & 0 & 100 & .3545702 & 4.783448 \\
INSTITUTIONAL FINANCE & 7,440 & 0 & 1 & .0202385 & .1016048 \\
SIZE & 2,941 & 0 & 316 & 5.15879 & 21.95097 \\
AGE & 7,452 & 2 & 78 & 8.594203 & 6.519793 \\
\hline
\end{tabular}

Table 2 shows the correlation matrix for all the variables used in the empirical study. The absences of high and significant correlation between the independent variables permit torejectproblemslinked to the effects of the nonsense correlation (Cohen et al., 2013).

Table 2 - Correlations

\begin{tabular}{llllllll}
\hline & 1 & 2 & 3 & 4 & 5 & 6 & 7 \\
\hline 1 & FINANCIAL PERFORMANCE & 1.0000 & & & & & \\
2 & IN-HOUSE FINANCE & $0.1524^{*} 1.0000$ & & & & \\
3 & DEBT FINANCE & $0.0766^{*}-0.0012$ & 1.0000 & & & \\
4 & EQUITY FINANCE & $0.0984 * 0.0003$ & 0.0121 & 1.0000 & & \\
5 & INSTITUTIONAL FINANCE & $0.1323^{*}-0.0571 * 0.0065$ & -0.0028 & 1.0000 & \\
6 & SIZE & $0.0459 * 0.0114$ & $0.0619 *$ & -0.0146 & -0.0295 & 1.0000 \\
7 & AGE & $0.0508^{*} 0.0214$ & -0.0332 & -0.0147 & $-0.0253^{*} 0.1995^{*} 1.0000$ \\
\hline
\end{tabular}

Notes: $* * \mathrm{p}<0.01 ; * \mathrm{p}<0.05$ (all two-tailed tests).

\subsection{Regression model estimation}

Table 3 shows the results of the linear regression models estimating of the impact of internal finance, debt finance and external equity finance on the financial performance of USOs. The regression analyses are performed in a stepwise manner. Model (1) includes all the control variables, while Model (2), (3), (4) and (5) refer to the principal effects, entered one by one.

In the Model (2), the estimated coefficient on IN-HOUSE FINANCE is slightly positive (almost irrelevant in practical term) statistically significant (coeff. $=0.0070, \mathrm{p}<0.001$ ), revealing that the internal financial resources generated by USOs have a marginal effect on the financial performance of the firm. In the Model (3), the estimated 
coefficient on DEBT FINANCE is positive and statistically significant (coeff. $=.0152399, \mathrm{p}<0.001$ ), showing that debt financing contributes to improve the financial development of USOs, although not a in a relevant manner.

In the Model (4), the estimated coefficient on EQUITY FINANCE is positive and statistically significant (coeff. = $.0155837, \mathrm{p}<0.001)$; denoting a similar result with the debt financing. Hence, debt and external equity financing, from industrial firm and individual owner, are useful form of external finance for USOs, although not enough to resilient rise their financial performance.

Finally, the Model (5), the estimated coefficient on INSTITUTIONAL FINANCE is positive and statistically significant (coeff. $=.9335841, \mathrm{p}<0.001$ ). The higher value of this estimate compared with those obtained by debt and external equity finance, indicates that institutional financing in the form of venture capital and private equity constitutes the most adequate form of finance for the effective financial development of USOs.

Table 3 - Linear regression estimates of the impact of internal funding, debt finance and external equity finance on the financial performance of the USOs

Dependent variable: financial performance

\begin{tabular}{llllll}
\hline Model & Model & Model & Model & Model \\
& $(1)$ & $(2)$ & $(3)$ & $(4)$ & $(5)$ \\
\hline
\end{tabular}

Main effects

IN-HOUSE FINANCE

DEBT FINANCE

EQUITY FINANCE

INSTITUTIONAL FINANCE

Control variables

AGE
SIZE
MANUFACTURING
ELECTRICITY GAS STEAM
AND AIR CONDITIONING
SUPPLY

CONSTRUCTION

WHOLESALE AND RETAIL

TRADE REPAIR OF

MOTOR VEHICLES AND

MOTORCYCLE

TRANSPORTATION AND

STORAGE

INFORMATION

COMMUNICATION

REAL ESTATE ACTIVITIES

PROFESSIONAL

SCIENTIFIC AND

TECHNICAL ACTIVITIES

ADMINISTRATIVE AND

SUPPORT SERVICE

ACTIVITIES

EDUCATION

HUMAN HEALTH AND

SOCIAL WORK

ACTIVITIES
$.0070071^{* * * *}$

(.0009389)

$.0152399 * * *$

(.0042843)

$.0155837 * * *$

(.0039768)

$.9335841 * * *$

(.1652526)

$\begin{array}{lllll}.000565 & .0009605 & .0030992 & .0018294 & .0009928 \\ (.0037134) & (.0036608) & (.0040474) & (.0037811) & (.0036832) \\ -.0000377 & -.0000533 & -.0001026 & -.0001999 & .0000938 \\ (.000879) & (.0008663) & (.0008927) & (.0008759) & (.0008719) \\ 1.790678 * * * & 1.791778 * * * & 1.830136 * * * & 1.815179 * * * & 1.543322^{* * *} \\ (.3748518) & (.3694165) & (.3929674) & (.3730693) & (.374293) \\ .8562837 & .8283825 & .8486431 & .8524904 & .8550001 \\ (.9682356) & (.9541618) & (.9707172) & (.9629377) & (.96015479 \\ .9142237 & .884283 & .9239743 & .9031731 & .9100255 \\ (.8745739) & (.8618649) & (.8774842) & (.8698161) & (.867275) \\ & & & & \\ 1.320654 & 1.262635 & 1.257828 & 1.33514 & 1.313569 \\ (.8795651) & (.8668104) & (.8842783) & (.875156) & (.8722251) \\ & & & & \\ 1.93711 * * & 1.842869 * * & 1.842736 * * & 1.894489 * * & 1.918875 * * \\ (.9041502) & (.8911012) & (.9082475) & (.8996596) & (.89661) \\ 1.537331 * * * & 1.533545 * * * & 1.611662 * * * & 1.554877 * * * & 1.306484 * * * \\ (.3673553) & (.3620134) & (.3846413) & (.3653729) & (.366574) \\ 1.137513 & 1.136198 & 1.027462 & 1.110431 & 1.13081 \\ (.8962487) & (.8832153) & (.9048876) & (.8914372) & (.8887694) \\ 1.568231 * * * & 1.570741 * * * & 1.630536 * * * & 1.574657 * * * & 1.303306 * * * \\ (.3710876) & (.365691) & (.3884738) & (.3691542) & (.3709664) \\ 1.004286 & & & & \\ (.8775371) & (.864796) & .8890518 & .9944739 & .9915319 \\ 1.624998 * & 1.659532 * & 2.460909 * * & 1.612118 * & 1.620939 * \\ (.918834) & (.9054829) & (.9709228) & (.9138209) & (.9111657) \\ 1.211946 & 1.209644 & 1.129208 & 1.197816 & 1.206222 \\ (.8921151) & (.8791416) & (.8977428) & (.8872809) & (.8846701) \\ & & & & \end{array}$




\begin{tabular}{|c|c|c|c|c|c|}
\hline \multirow{2}{*}{$\begin{array}{l}\text { ARTS ENTERTAINMENT } \\
\text { AND RECREATION }\end{array}$} & $1.524974 *$ & $1.499145^{*}$ & 1.496437 & 1.497901 & $1.509582 *$ \\
\hline & (.919212) & $(.9058512)$ & $(.9216916)$ & $(.9142257)$ & $(.9115443)$ \\
\hline $\begin{array}{l}\text { OTHER } \\
\text { ACTIVITIES }\end{array}$ & $\begin{array}{l}.507276 \\
(.9424769)\end{array}$ & $\begin{array}{l}.5083627 \\
(.9287703)\end{array}$ & $\begin{array}{l}.6059756 \\
(.9511381)\end{array}$ & $\begin{array}{l}.5217586 \\
(.9374004)\end{array}$ & $\begin{array}{l}.2850599 \\
(.9354383)\end{array}$ \\
\hline Number of obs & 1,845 & 1,844 & 1,640 & 1,808 & 1,845 \\
\hline $\mathbf{F}$ & $5.00 * * *$ & $8.33^{* * *}$ & $5.63^{* * *}$ & $5.74 * * *$ & $6.76 * * *$ \\
\hline R-squared & 0.0394 & 0.0680 & 0.0526 & 0.0488 & 0.0559 \\
\hline Adj R-squared & 0.0315 & 0.0598 & 0.0432 & 0.0403 & 0.0476 \\
\hline Root MSE & .86596 & .85337 & .86817 & .86122 & .85873 \\
\hline
\end{tabular}

Notes: values in the parentheses are standard errors. $* * * \mathrm{p}<0.001 ; * * \mathrm{p}<0.01 ; * \mathrm{p}<0.10$; (all two-tailed tests). ${ }^{\mathrm{b}}$ This parameter is set to zero because it is redundant.

\section{Conclusions}

The research aimed to investigate the financing sourcing of the USOs, i.e., the in-house finance, the debt finance and equity finance, and their impact on the financial performance of the USOs. Some key conclusions emerging from the analyses conducted. First, the results highlight a positive but low effect of in-house finance on the USOs' financial performance, hence its impact is too weak to increment the financial development of the firm. This result remarks that the financial performance of university-based firms is not fully explained by internal sources of funding.

With regard to the effect of debt finance, the results show a positive impact on the financial performance of USOs, which is higher compared to the in-house finance. This evidence points out that debt constitute a key financial instrument to the economic development of USOs, remaking the bank-based influence of a country such as Italy.

Taking into account the effect of equity finance on the financial performance of the USOs, the evidenceis comparable to those associated with the effect of debt finance. This means a significant role of the equity-based finance in improving the performance dynamics of the university-based firms.

However, the most significant impact on the financial performance of the USOs is exercised by the institutional investors in the form of venture capital and private equity. This evidence shows that, in the entrepreneurial university context, these dedicated investors have the most beneficial and central role in improving the financial development of university-based firms.

Hence, the USOs analyzed seems not be affected by the information asymmetry issues that usually affect innovative start-ups and new technology-based firms, such as the USOs, between the firm and investor. In this emerging setting, the institutional investor is the most prominent financial provider for the full development of the USOs, contributing to support the growth and financial strategy of the firm and providing organizational and managerial expertise too.

\section{References}

Agarwal, R., Echambadi, R., Franco, A. M., \& Sarkar, M. B. (2004). Knowledge transfer through inheritance: Spin-out generation, development, and survival. Academy of Management journal, 47(4), 501-522.

Alvarez, R., Benavente, J. M., \&Crespi, G. (2019). Innovation in the Global Economy: Opening-Up Latin American Innovation Systems. Banco Interamericano de Desarrollo, Washington, DC. Documento inédito.

Audretsch, D. B., Lehmann, E. E., \& Wright, M. (2014). Technology transfer in a global economy. The Journal of Technology Transfer, 39(3), 301-312.

Balderi, C., \&Piccaluga, A. (2010). A theoretical and empirical contribution for a better understanding of academic spin-offs' growth patterns (No. 201004).

Balderi, C., Patrono, A., \&Piccaluga, A. (2011). La ricerca pubblica e le sue perle: le imprese spin-off in Italia. Quadernidell'Istituto di Management, 1, 2011.

Barney, J. B. (2001). Resource-based theories of competitive advantage: A ten-year retrospective on the resourcebased view. Journal of management, 27(6), 643-650.

Bolzani, D., Fini, R., Grimaldi, R., \&Sobrero, M. (2014). University spin-offs and their impact: Longitudinal evidence from Italy. Economia e politicaindustriale. 
Buckley, P. J., \&Hashai, N. (2020). Skepticism toward globalization, technological knowledge flows, and the emergence of a new global system. Global Strategy Journal, 10(1), 94-122.

Carpenter, R. E., \& Petersen, B. C. (2002). Capital market imperfections, high- tech investment, and new equity financing. The Economic Journal, 112(477), F54-F72.

Cho, D. W., \&Shenkoya, T. (2020). Technology transfer: economic factors that influence transferor and transferee's choice. Technology Analysis \& Strategic Management, 32(6), 621-633.

Colombo, M. G., \&Grilli, L. (2010). On growth drivers of high-tech start-ups: Exploring the role of founders' human capital and venture capital. Journal of business venturing, 25(6), 610-626.

Davidsson, P., \&Henrekson, M. (2002). Determinants of the prevalance of start-ups and high-growth firms. Small business economics, 19(2), 81-104.

Fini, R., Rasmussen, E., Siegel, D., \&Wiklund, J. (2018). Rethinking the commercialization of public science: From entrepreneurial outcomes to societal impacts. Academy of Management Perspectives, 32(1), 4-20.

Florio, M. (2019). Investing in science: social cost-benefit analysis of research infrastructures. MIT Press.

Gaud, P., Hoesli, M., \& Bender, A. (2007). Debt-equity choice in Europe. International Review of Financial Analysis, 16(3), 201-222.

Guerrero, M., \&Urbano, D. (2012). The development of an entrepreneurial university. The journal of technology transfer, 37(1), 43-74.

Guerrero, M., Urbano, D., Fayolle, A., Klofsten, M., \&Mian, S. (2016). Entrepreneurial universities: emerging models in the new social and economic landscape. Small Business Economics, 47(3), 551-563.

Heirman, A., \&Clarysse, B. (2004). How and why do research-based start-ups differ at founding? A resource-based configurational perspective. The Journal of Technology Transfer, 29(3-4), 247-268.

Huynh, T., Patton, D., Arias-Aranda, D., \& Molina-Fernández, L. M. (2017). University spin-off's performance: Capabilities and networks of founding teams at creation phase. Journal of Business Research, 78, 10-22.

Kull, A. J., Mena, J. A., \&Korschun, D. (2016). A resource-based view of stakeholder marketing. Journal of Business Research, 69(12), 5553-5560.

Lappalainen, J., \&Niskanen, M. (2012). Financial performance of SMEs: impact of ownership structure and board composition. Management researchreview.

Lazzeri, F., \&Piccaluga, A. (2012). Le imprese spin-off della ricerca pubblica: convinzioni, realtà e prospettive future. Economia e societàregionale, 1, 43-65.

Mathisen, M. T., \& Rasmussen, E. (2019). The development, growth, and performance of university spin-offs: a critical review. The Journal of Technology Transfer, 44(6), 1891-1938.

Minola, T., Hahn, D., \& Cassia, L. (2019). The relationship between origin and performance of innovative startups: the role of technological knowledge at founding. Small Business Economics, 1-17.

Oskarsson, I., \&Schläpfer, A. (2008). The Performance of Spin-off Companies at the Swiss Federal Institute of Technology Zurich: Thesis for the Masters in Finance Program (MSc Finance) at London Business School. ETH-Transfer.

Petricevic, O., \& Teece, D. J. (2019). The structural reshaping of globalization: Implications for strategic sectors, profiting from innovation, and the multinational enterprise. Journal of International Business Studies, 50(9), 1487-1512.

Prokop, D., Huggins, R., \& Bristow, G. (2019). The survival of academic spinoff companies: An empirical study of key determinants. International Small Business Journal, 37(5), 502-535.

Rodríguez-Gulías, M. J., Fernández-López, S., \&Rodeiro-Pazos, D. (2016). Growth determinants in entrepreneurship: A longitudinal study of Spanish technology-based university spin-offs. Journal of International Entrepreneurship, 14(3), 323-344.

Soete, L. (2014). Research and Innovation for Sustainable Development. In Technologies for Sustainable Development (pp. 239-244). Springer, Cham.

Vanacker, T. R., \&Manigart, S. (2010). Pecking order and debt capacity considerations for high-growth companies seeking financing. Small Business Economics, 35(1), 53-69.

Vanacker, T. R., Heughebaert, A., \&Manigart, S. (2014). Institutional frameworks, venture capital and the financing of European new technology- based firms. Venture Capital and the Financing of European New Technology- Based Firms (May 2014). Corporate Governance: An International Review, 22(3), 199-215.

Yagüe-Perales, R. M., \& March-Chordà, I. (2012). Performance analysis of research spin-offs in the Spanish biotechnology industry. Journal of Business Research, 65(12), 1782-1789. 